\title{
Business Cluster and Entrepreneurship Growth in Nigeria: A Systematic Review
}

\author{
Isiaka Kolawole Mustapha \\ Federal University of Technology, Minna Nigeria \\ Email:mikola0507@yahoo.com \\ Umaru Mustapha Zubairu \\ Federal University of Technology, Minna Nigeria \\ Email: uzubairu@gmail.com \\ Olalekan Busra Sakariyau \\ Federal University of Technology, Minna Nigeria \\ Email: zaksconsults@,gmail.com
}

\begin{abstract}
The research in business clusters $(B C)$ system of entrepreneurship development has increased in the recent year. A plethora of research has explored; entrepreneurship and urban growth, the entrepreneurial attitudes on the structure of support for entrepreneurship in an ecosystem, the effect of business clusters on firm performance and more recently, the dimension of agglomeration, institution and environment on business clusters. With the aid of Systematic Qualitative Assessment Techniques (SQAT), we review 79 business cluster journal articles published over the last 11 years (20102020) that sought to provide BC antecedent and impact on entrepreneurship and economy growth to provide a point for future research. Also, the review provides the geographic distribution, time distribution, underlying drivers of previous research, types and method of data collection used by these BC articles. Our findings shed light on the key themes including the evolution of $B C$, the impact of $B C$ on the economy, application of $B C$ s and the public policy maker roles. Furthermore, there is a dearth of $B C$ research in Africa, South America and Australasia with most $B C$ research are empirical and this represents gaps for future researchers to explore.
\end{abstract}

\section{Keywords: business cluster, entrepreneurship, systematic review}

Received: 27 April 2021;

Accepted: 2 June 2021 ;

Publish: June 2021

\section{How to Cite:}

Mustapha, I.K., Zubairu, U.M., \& Sakariyau, O.B. (2021). Business Cluster and Entrepreneurship Growth in Nigeria: A Systematic Review. Journal of Business and Behavioural Entrepreneurship, 5(1), 92-108. https://doi.org/10.21009/JOBBE.005.1.06 


\section{INTRODUCTION}

The concept of cluster or agglomeration of business is not a new theory and has received global interest in the last few years. The recognition and attention given to the concept of business formation are closely related to small and medium enterprises (SMEs) and economic growth in a country. The inherent benefits of business cluster formation have manifested in many fields of endeavour including information technology in Silicon Valley, the automobile in Germany, the wristwatch in Switzerland and the financial sector on Wall Street. This assertion explains why other country or group of people are using the initiative of clustering. From a historical point of view, Porter (1998) first use the word "clusters" to mean a geographic concentration of interrelated entrepreneur and/or companies in a particular region to foster the development of their trade (Sword, 2013).

There is no gainsaying that researches on business clusters has been carried out from various perspectives such as, being strongly linked to entrepreneurship development and entrepreneurial skill innovation (Bourletidis, 2014; Lalzuitluani and Ramswamy, 2019). Several other studies demonstrate that geographical agglomeration of businesses provides enabling environment for public policy makers and government agencies in terms of formulating sustainable and longer-term policy that is considered to have a positive impact on regional growth ( $\mathrm{Yu}$ et al., 2013; Njos and Jakobsen, 2016; Vernay, et. al., 2018) and it also creates enterprises competitive advantage leading to innovation and growth (Rocha, 2015; Ferras-Hernandez and Nylund, 2019).

Although, there is consensus towards the importance of business clusters for regional and economic growth (Xue and Liu, 2015; Herliana, 2015). However, the reason why businesses in close proximity are not creating the necessary expected benefits or opportunities is still a point of discussion. Hence, empirical researches are being carried out on business clusters as it affects - tourism industry (Fundeanu, 2015), the fashion industry (Ganzaroli and Noni, 2017), digital and multimedia industry (Adebanjo and Roula, 2010; Mitra and Thorpe, 2010), organization research and development (Nishimura and Okamuro, 2010). Also research on how business clusters can be used to survive any economic crisis and reduce the poverty rate (Fowler and Keit, 2013; Wardhana and Heijman, 2017). Works of literature on the applicability and public policy on business clusters is still emerging especially in Africa and South America. As regards the sustainability of business clusters set up through public initiation, the research gap is clearly shown. Thus, there is a need to appropriately investigate the positive relationship between public policy formulation and business cluster concept in recent literature.

Against the foregoing, this systematic review intends to focus on business clusters and entrepreneurial development, drawing strength from policy initiation and implementation by various institutions and agencies of the Nigeria government saddled with such responsibilities. This deliberate action is geared towards assessing the impacts government policies has made thus far on business clusters and entrepreneurial development. The exploratory work will also enable us to segment component of each cluster under discourse.

Thus, research publications on business clusters in the last ten years (2010 2020) were analysed. Papers in the review were sourced from seven databases: Elsevier, Emerald, InderScience, Sage, Springer, Taylor \& Francis and Wiley. These databases were chosen based on the quality of their peer-reviewed paper publication. To achieve the aim of this study, the business clusters concept was analysed with its different dimensions and its relation to other aspects of entrepreneurial development. This 
was done by analysing the downloaded papers on the following factors: geographical distribution, time distribution, type of articles (empirical vs. conceptual), theories used, theme and the data collection methods. The systematic review enables us to develop a proper perspective of the previous research and to identify research gaps in business clusters that will set the agenda for future research.

This paper is divided into four sections and structured as follows: besides this first section - introduction, the second section discusses the methodology used in conducting this systematic review. The third section presented the findings and proposes agenda for future research based on the research result. The fourth and final section presented an area of discussion on limitations and conclusion.

\section{RESEARCH METHOD}

This systematic review of BC over the last eleven years $(2010-2020)$ is conducted using the Systematic Quantitative Assessment Technique (SQAT) developed in 2014 by Pickering and Byrne. A systematic review is said to be "a review using a systematic method to summarize evidence on questions with a detailed and comprehensive plan of study" (Tawfik, et al., 2019, p.1). The SQAT enable researchers to apply a filtering process in the selection process of peer-reviewed journals publication to maintain a high standard of articles. The technique provides easy analysis, usage and easily replicated systematic review which is a very important component of research of this nature (Zubairu, 2019).

The basic five steps recommended by SQAT in conducting an effective systematic review was described how it was applied in this review is described in Table 1.

Table 1

Description of systematic review steps

\begin{tabular}{|c|c|c|}
\hline $\mathbf{S} / \mathbf{N}$ & Step & Application in current study \\
\hline & Define topic & $\begin{array}{l}\text { Business Cluster (BC) articles published between } 2010 \text { and } \\
2020 \text {. }\end{array}$ \\
\hline & $\begin{array}{l}\text { Framing research ques- } \\
\text { tions }\end{array}$ & $\begin{array}{l}\text { Six research questions were formulated on the topic business } \\
\text { cluster: } \\
\text { What is the time distribution of business cluster articles? } \\
\text { What are the geographical distribution of the articles? } \\
\text { What type of business cluster articles were published? } \\
\text { (Conceptual vs. Empirical) } \\
\text { What theories were discussed or developed in articles } \\
\text { downloaded? } \\
\text { What are the themes of article reviewed and major find- } \\
\text { ings? } \\
\text { What method of data collection were employed by the re- } \\
\text { searchers? }\end{array}$ \\
\hline & Identify key words & "Business Cluster" + "entrepreneurship" \\
\hline & $\begin{array}{l}\text { Identifying relevant publi- } \\
\text { cations and search data- } \\
\text { base. }\end{array}$ & $\begin{array}{l}\text { Seven databases were used: Elsevier, Emerald, In- } \\
\text { derScience, Sage, Springer, Taylor \& Francis, and } \\
\text { Wiley. } \\
\text { "All in title" and "Anywhere in the Article" search criteria. } \\
\text { "Business Cluster" + "entrepreneur" }\end{array}$ \\
\hline & $\begin{array}{l}\text { Summarize the result and } \\
\text { interpret the findings }\end{array}$ & $\begin{array}{l}\text { Abstract of the downloaded articles were read to understand } \\
\text { their findings on business clusters } \\
\text { Findings were presented and research gap analysed. Also, } \\
\text { agenda for future research was presented. }\end{array}$ \\
\hline
\end{tabular}


A total of 79 peer-reviewed articles on business clusters were selected from seven databases. Literature reviews, books chapters and conference papers were not included in this review. Table 2 presents the total number of articles downloaded from each database.

Table 2

Number of articles downloaded in database

\begin{tabular}{|r|l|c|}
\hline S/N & \multicolumn{1}{|c|}{ Publishers } & Numbers of Papers \\
\hline 1 & Elsevier & 17 \\
\hline 2 & Emerald & 12 \\
\hline 3 & InderScience & 11 \\
\hline 4 & Sage & 14 \\
\hline 5 & Springer & 3 \\
\hline 6 & Taylors \& Francis & 12 \\
\hline 7 & Wiley $\quad$ Total & $\mathbf{7 9}$ \\
\hline & \multicolumn{2}{r}{} \\
\hline
\end{tabular}

Sources: Authors' review (2021)

\section{RESULT AND DISCUSSIONS}

\section{TIME DISTRIBUTION OF ARTICLES ON BUSINESS CLUSTERS}

The analysis of the $\mathrm{BC}$ articles review shows that the highest number of articles was published in the year 2014 (17) followed by 2015 (11) and 2010 (11) respectively. 2018 (2) and 2020 (2) had the fewest number of business cluster articles published, whilst business clusters articles were published in each of the eleven years (20102020) covered by this systematic review (Figure 1). The 2014 spike in the researched published could be due to economic recovery activities around the world, over $50 \%$ of $\mathrm{BC}$ articles for 2014 reviewed discussed initiatives, developmental policies and models developed by the government or institutional organisation to increase the BC's impact on the economic development (e.g. Alberti, et al., 2014; Fundeanu and Badele, 2014; Garone, et al., 2014; and Wolman and Hincapie, 2014).

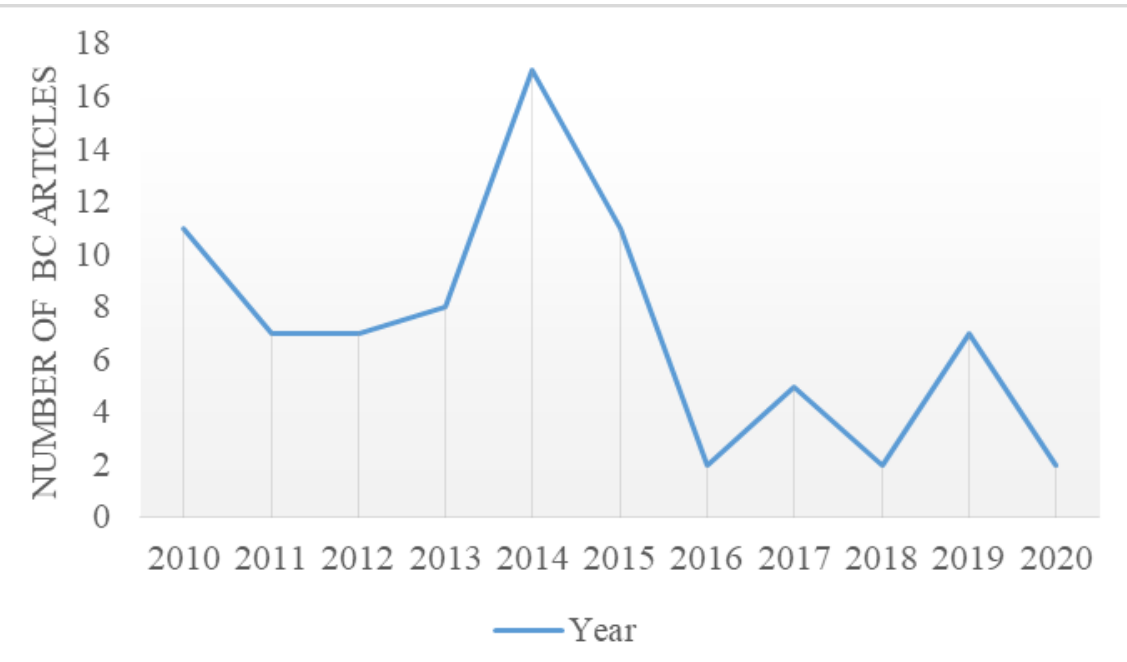




\section{Figure 1: Time distribution of $\mathrm{BC}$ articles}

Source: Authors' review (2021)

It can be observed that the number of $\mathrm{BC}$ articles published decrease significantly in the year 2020 (2), this could be due to the impact of COVID 19 on businesses. Lockdown of business concentration and the practice of social distancing. A future research area could be the impact of a pandemic on business cluster performance.

\section{GEOGRAPHIC DISTRIBUTION OF ARTICLES ON BUSINESS CLUSTER}

Analysis of the $79 \mathrm{BC}$ articles showed that 34 countries were represented in the systematic review of $79 \mathrm{BC}$ articles reviewed. The top three countries from which these are articles originated were presented in Figure 2.

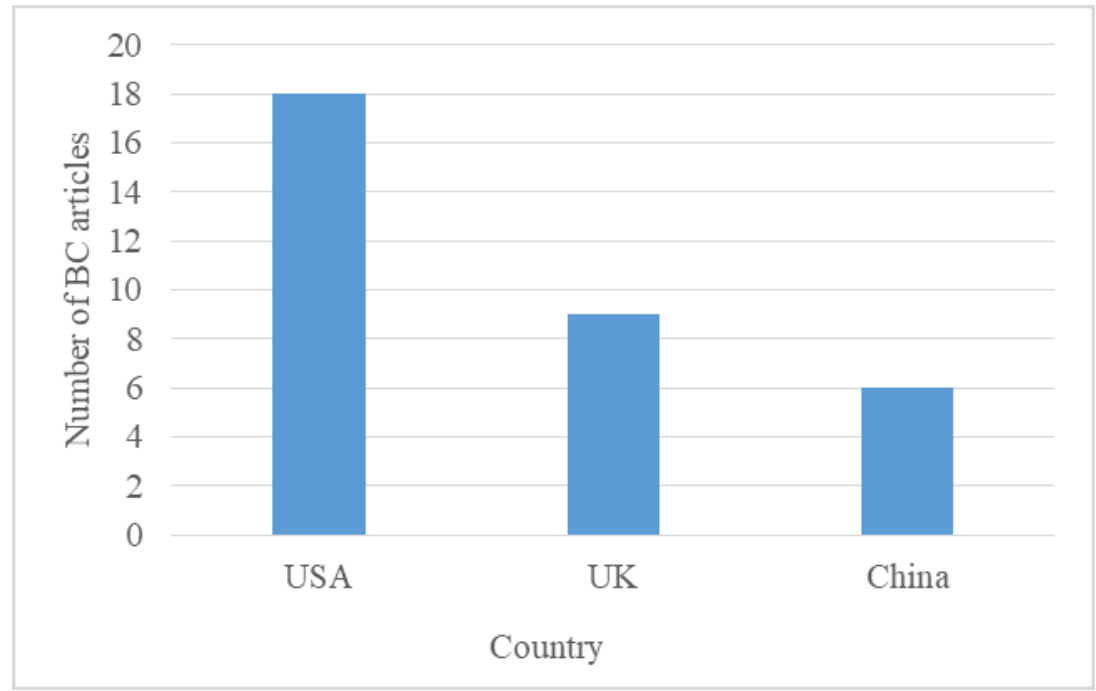

Figure 2: Countries with highest $\mathrm{BC}$ articles

Source: Authors' review (2021)

The United States of America (18), followed by the United Kingdom with distant nine and then China with six BC articles. The remaining 32 countries and the number of articles published on $\mathrm{BC}$ are presented in Table 3.

To provide more insight into the geographical distribution of the $79 \mathrm{BC}$ articles reviewed in the study, Figure 3 show a breakdown of the continent of origin.

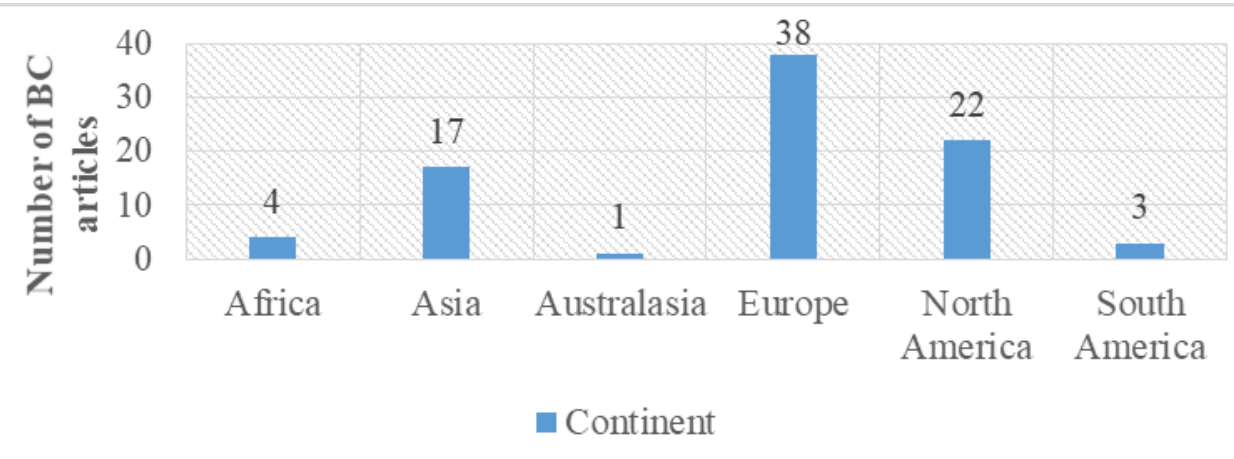


Figure figure 3: Geographic distribution of $\mathrm{BC}$ articles

Source: Authors' review (2021)

Based on the analysis of the 79 reviewed articles, Europe has the highest number of published articles (38), followed by both North America (22) and Asia (17). Other continents had - Africa (4), and South America (3) and Australasia (1) has the least. This clearly shows geographical gaps in business cluster research in Africa, South America and Australasia.

A significant amount of research has shown that entrepreneurship is an important engine for economic growth through; innovation and productivity (Islam, 2010; Nishimura and Okamuro, 2010; Carlino and Kerr, 2015); generating employment, (Glaeser, et al, 2010); increase competitive advantage, (Mitra and Thorpe, 2010, Fundeanu, 2015); and through the development of technological park and business clusters (Rocha, 2015). Business clusters have also been identified as an important mechanism through which entrepreneurs can improve their value creation potentials by sharing resources and ideas (e.g. Selvarajah and Masli, 2011; Champenois, 2012; Dilaver, et al. 2014; Kim, 2014; Huggins, et al. 2015; Herliana, 2015; Lalzuitluangi and Ramswamy, 2019). For these reasons, more research must be done to investigate the role of business clusters in entrepreneurship development in Australasia, Africa and South America.

Table 3.

32 remaining countries and the $\mathrm{BC}$ articles associated with them

\begin{tabular}{r|l|c}
\hline \multicolumn{1}{c|}{$\begin{array}{c}\text { S/ } \\
\text { No. }\end{array}$} & Country & $\begin{array}{c}\text { Number of } \\
\text { articles }\end{array}$ \\
\hline 1 & Italy & 5 \\
\hline 2 & Netherland & 4 \\
\hline 3 & Canada & 4 \\
\hline 4 & Romania & 3 \\
\hline 5 & Spain & 3 \\
\hline 6 & Sweden & 3 \\
\hline 7 & France & 2 \\
\hline 8 & Norway & 2 \\
\hline 9 & India & 2 \\
\hline 10 & Malaysia & 2 \\
\hline 11 & Brazil & 2 \\
\hline 12 & Ethiopia & 2 \\
\hline 13 & Australia & 1 \\
\hline 14 & Czech & 1 \\
\hline 15 & Denmark & 1 \\
\hline 16 & Germany & 1 \\
\hline
\end{tabular}

\begin{tabular}{r|l|c}
\hline $\begin{array}{l}\text { S/ } \\
\text { No. }\end{array}$ & Country & $\begin{array}{l}\text { Number of } \\
\text { articles }\end{array}$ \\
\hline 17 & Greece & 1 \\
\hline 18 & Lithuania & 1 \\
\hline 19 & Poland & 1 \\
\hline 20 & Serbia & 1 \\
\hline 21 & Switzerland & 1 \\
\hline 22 & Latvia & 1 \\
\hline 23 & Ireland & 1 \\
\hline 24 & UAE & 1 \\
\hline 25 & Indonesia & 1 \\
\hline 26 & Japan & 1 \\
\hline 27 & Pakistan & 1 \\
\hline 28 & Singapore & 1 \\
\hline 29 & Taiwan & 1 \\
\hline 30 & Thailand & 1 \\
\hline 31 & Nigeria & 1 \\
\hline 32 & Ghana & 1 \\
\hline
\end{tabular}

Sources: Authors' review (2021)

Country analysis of the 79 articles reviewed shows 35 countries had business clusters research published. According to Worldometers.info, there are 197 independent sovereign states in the world. The review shows that less than $20 \%$ had business 
cluster research published, this is rather too low on a concept that is likely to contribute to the innovation and productivity growth of each country (Islam, 2010). It is important to also state that some researches were carried out in multiple countries, nonetheless, many countries are not represented in the business clusters research. Therefore, there is a need for researchers in all countries to research business clusters. This will help identify the impact of successful business clusters and how policy makers can utilize the concept of business clusters in growing their economy.

\section{ARTICLE TYPE}

The 79 articles used for the systematic review was further analysed based on research type: empirical or conceptual. Empirical articles are those research conducted through investigation or observation, and the findings are based on a collection of data evidence while conceptual articles focus on the development of a theory that explains a phenomenon or event. Figure 4 shows the analysis of the 79 articles based on the empirical vs conceptual classification.

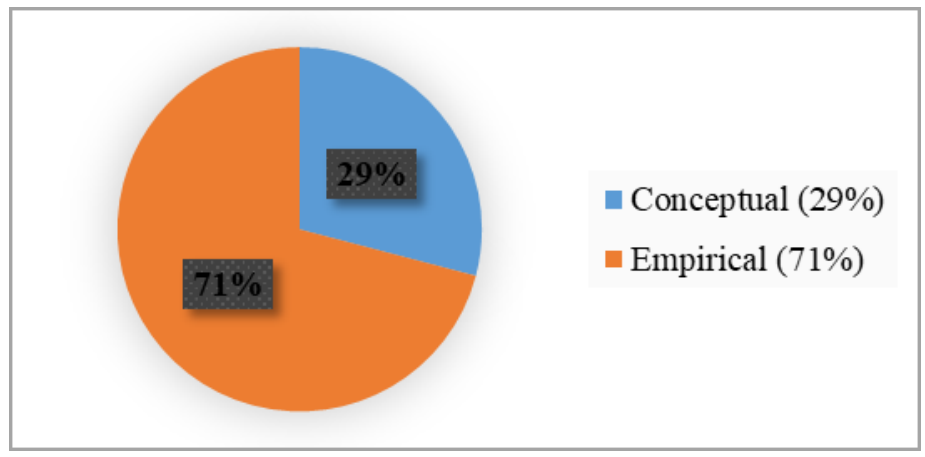

Figure 4: Article Type Breakdown

Sources: Authors’ Review (2021)

The articles reviewed indicates significant numbers were empirical $(71 \%, 56$ out of 79). Articles that are based on conceptual research are 23 out of 79 (29\%). Empirical research help in testing the postulated theories and give more meanings to abstract ideas through practical and experimental observation. Conceptual research, on the other hand, is important as it helps in developing new ideas in solving real-world identified problems and also providing the direction for future empirical research. (Zina, 2021). Therefore, there is a need for more conceptual research to be carried out on business clusters.

\section{THEORY BREAKDOWN OF BUSINESS CLUSTERS RESEARCH}

The analysis of theories used in the $79 \mathrm{BC}$ journals reviewed is shown in Figure 5 below. 


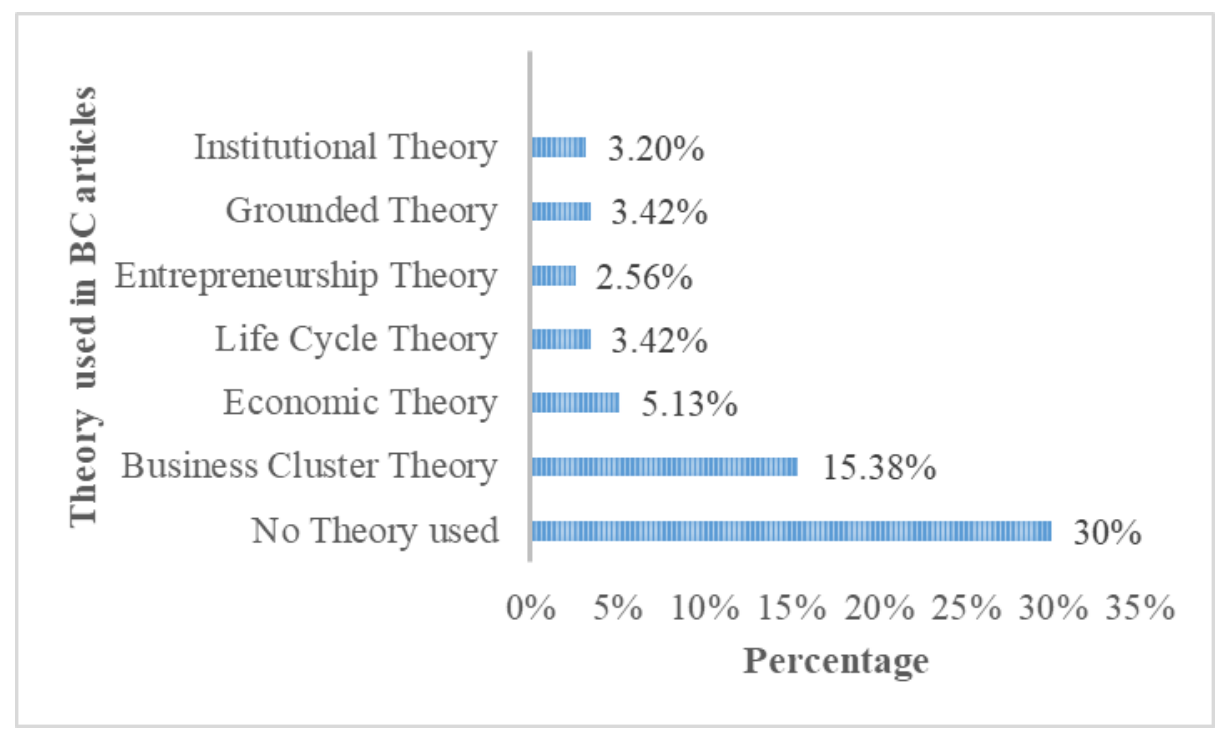

Figure 5: Analysis of Theory Used.

Sources: Authors' Review (2021)

The analysis of the 79 journal articles shows that 35 theories were utilized. Although, a significant number of the articles did not utilize any theory in their analysis $(30 \%)$ of business clusters. The most utilized theory is the Business Cluster theory $(15.38 \%)$ followed by the Economic Theory $(5.13 \%)$, then Life Cycle Theory $(3.42 \%)$ and Grounded Theory (3.42\%). Some articles used more than one theory (e.g. De Sordi et al., 2013; Rocha, 2015; and Hervas-Oliver et al., 2017) - Knowledge spill-over theory, organization theory, peer learning theory and agency theory are among other theory used.

The business cluster theory provides insights on how the concentration of entrepreneurial innovation within a region helps in economic development (Hill and Mudambi, 2010; Alberti et al., 2011). It also provides information on the availability of abundant capital which facilitates business co-operation and the formation of a new firm (Hervas-oliver, et al. 2017). Economic theory is used in identifying the impact of entrepreneurship and business cluster on the rate of economic growth and the increase in quality of public policymaking (Huggins, et al., 2017). Life cycle theory reveals the basis for developing business clusters on each stage of the economic cycle: growth, decline and stagnation (Wang, et al. 2014).

A business cluster is stated to be an important part of Entrepreneurship theory dynamics. The entrepreneurship theory is used to describe how clusters foster entrepreneurship (Yan, et al., 2011). Grounded theory is employed to build a framework that explains the process of cluster development (Kim, 2014). Institutional theory is used to demonstrate the dynamic process for institutional change in business clusters (Rocha, 2015).

Several theories were used in the articles analysed, this may mean the need to have more empirical research to test the interrelationship of these theories with business clusters. Empirical research helps in investigating the developed theories (Zina, 2021). Though most articles reviewed did not use any theory to support their research. 


\section{BUSINESS CLUSTER RESEARCH THEMES}

The analysis of the 79 articles on business clusters indicates four main themes of research which are presented in Figure 6.

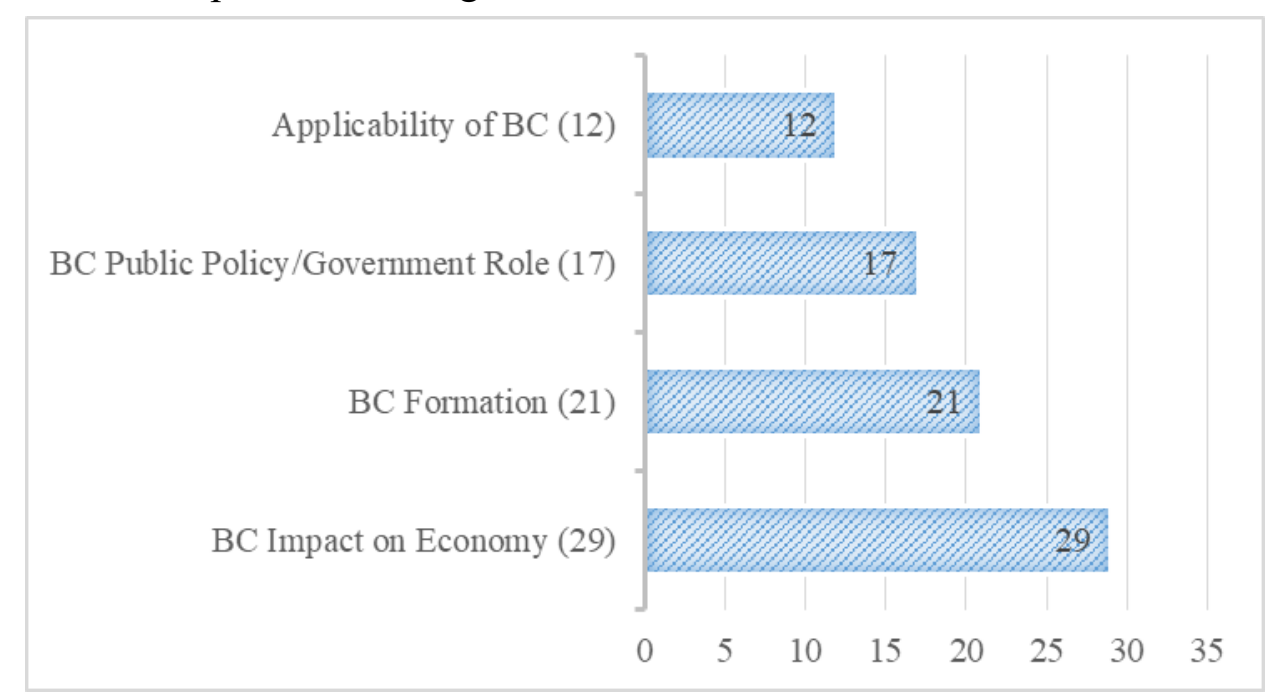

Sources: Authors' Review (2021)

Figure 6: Business Cluster Themes

The most common business clusters theme explored by the articles reviewed was the impact of $\mathrm{BC}$ on the economy $(37 \%, 29$ out of 79$)$. These articles highlighted opportunities and benefits that a region with a business cluster enjoys. The presence of business clusters in the region is noted to help in reducing poverty rate; increases employment rate especially where there is diverse industry cluster; enhances firm performances, create international business links and entrepreneurial growth (e.g. Kukalis, 2010; Islam, 2010; Alberti, et al., 2011 Ali and Peerlings, 2012; Fowler and Keit, 2013; Rocha, 2015).

Geographical concentration of small business also promotes entrepreneurship innovation and increases tacit knowledge (Richardson, et al., 2012), this is because of attributes related to business clusters such as face-to-face communication, business attitude, attractions, rivalry - developing a competitive advantage, and social factors (Ferras-Hernandez and Nylund, 2019). However, Letaifa and Rabeau, (2013) noted that business cluster created through entrepreneurship spontaneous ecosystem are more prone to innovation that those driven by government policy.

The second common theme among the business cluster article reviewed (27\%) discussed the "Business Cluster Formation" (21 out of 79). BC formation was explored by the journal reviewed to presents details of its evolution (e.g. Guisard, et al., 2010; Hill and Mudambi, 2010; Wang, et al., 2013). Kukalis, (2010); Constantin et al., (2011) and Wang, et al., (2013), used the theory of industry life cycle to explain the process of business cluster formation which depicts the stages of how businesses operate from conception to maturity before it reaches declining stage. Spatial concentration of entrepreneurship activities within a region is another way by which business clusters are formed. Integration network services, social connection and marketing brought about through entrepreneurs innovation, human capacity or spin-off of existing business by a bigger firm to explore a new potentials (e.g. Dilaver, et al., 2014; Huggins et 
al., 2015; Hervas-Oliver, et al., 2017).

The 21 articles analysed under the BC formation theme revealed that business cluster can emerge from any region based on such regions' social factors that create the enabling environment (e.g. Rosiello, et al., 2015; Gordon and Kourtit, 2019). For example, the resources needed by financial industry cluster - such as access to security, proximity to high net worth clients and skilled labour may differ (in some aspect) from that of farmers' cluster that have may have interest in good road network and presence of off-takers or access to a market for their produce. Challenges in the development of business clusters may be addressed through favourable government policy initiatives.

The third theme of the business cluster articles reviewed was government policy role (17 out of $79 \%$ ). These articles provide information on how government agency create enabling environment (good infrastructure, access to finance, technical expertise, and training) for the sustainability of business clusters through a moderating role (Steiner and Ali, 2011; Casper, 2013; Wolman and Hincapie, 2014). However, the government agency role should only be to facilitate or in form of intervention to reinforce established clusters, this is because a business cluster established by the government through public policy may not simulate the development needed like spontaneous or informal business network (Richardson, et al., 2012; Yu, et al., 2013; Vernay, et al., 2018).

De Sordi, et al. (2013) noted the need for classification of business clusters to understand their workings to determine the type of policy intervention or government role needed to create the value envisioned. Such intervention is expected to impact positively on innovative activities, increase regional competitive advantage, increase employment, improve knowledge sharing; eliminate international barriers and promotion of cluster growth (Steiner and Ali, 2011). Therefore, the research theme indicates a gap in the application of the business cluster concept, as well as the role of policymakers in making business cluster sustainable. Hence, the need for research in these areas. Especially in Africa, South America and Australasia that have fewer researches as indicated in the analysis of the geographical distribution of business cluster articles. This will be beneficial to society and lead to business growth.

The last theme from the business cluster research reviewed was the applicability of business clusters $(15 \%, 12$ out of 79$)$. These articles provide insights into how business clusters can be used to create the needed opportunities for regional growth. The applicability of the Business Cluster has the potential to facilitate individual/firm participation and increase connectivity among firm in - the digitally clustered business (Adebanjo and Roula, 2010), the tourism industry - to create competitiveness (Fundeau, 2015), as well as in fashion industry (Ganzaroli and Noni, 2017).

The reasons for adopting the business clusters by region were revealed as it helps to maximize firm growth, create longer-term sustainability, enhances innovation and create a soft landing for the economy during an economic crisis (Schmiedeberg, 2010; Kassai, et al., 2018;). These articles identified that business clusters play an important role in developing entrepreneurship especially among the small agricultural enterprises (Lalzuitluani and Ramswamy, 2019). Therefore, more cities need to embrace the cluster concept in other to improve their economic growth and competitiveness albeit with support policies from a government agency.

\section{DATA COLLECTION METHODS}

In this section, the data collection methods used by empirical $\mathrm{BC}$ journal articles re- 
viewed are identified and discussed. As can be recalled from the "Article Type" section of this study, 56 out of the $79 \mathrm{BC}$ articles reviewed were empirical studies. The breakdown of the data collection methods utilized by these 52 journal articles is presented in Figure 7.

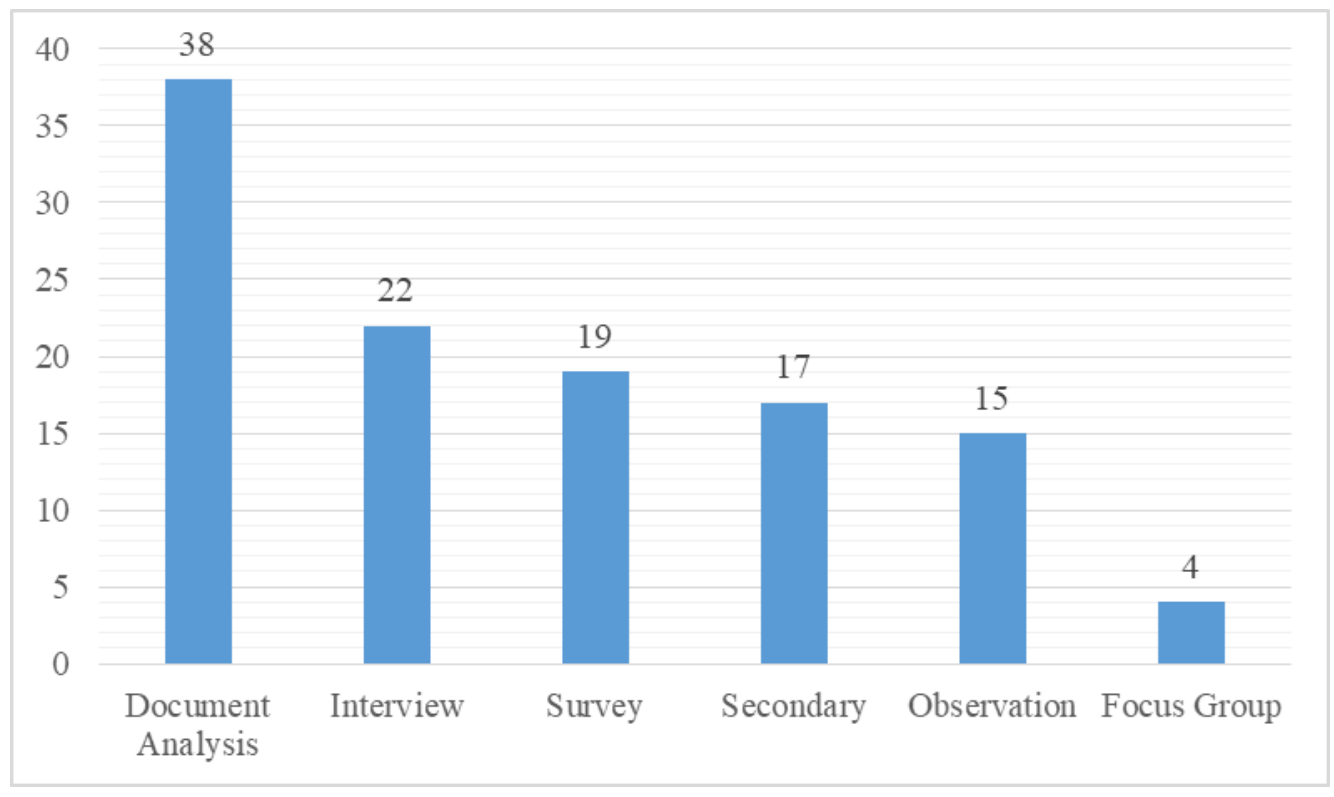

Sources: Authors' Review (2021)

Figure 7: Data Collection Methods

Six different data collection methods were utilized by the 52 empirical BC articles reviewed for this study. It can be observed from Figure 7 that the most used data collection method was a reliance on document analysis method. $33 \%$ of the BC articles (38 out of 115) indicating the most utilized method (e.g. Xue and Liu, 2015; Huang et al., 2017; Vernay et al., 2018; Ma and Liu, 2019; Pereira et al., 2020). Interviews were the next most common method of data collection (22 out of 115) (e.g. Rauch et al., 2014; Hervas-Oliver et al., 2017; Kassai et al., 2018). This is closely followed by survey (19 out of 115) (e.g. Negrușa et al., 2014; Rosiello et al., 2015; Ayakwah et al., 2020) and secondary data (17 out of 115) (e.g.; Alberti et al., 2014;; Foley et al., 2017; Lalzuitluani and Ramswamy, 2019). Fifteen articles collected data using observation method (e.g. (e.g. Alberti and Gusti, 2012; Kim, 2014; Negrușa et al., 2014) while four articles organized focus groups (Adebanjo and Roula, 2010; Madichie and Nkamnebe, 2010; Selvarajah and Masli, 2011; Letaifa et al., 2013).

It is worthy to mention that some articles employ more than one data collection method in their analysis. Two articles, Alberti and Giusti (2012) and Letaifa et al., (2013) employed four methods to collect data. Four articles reviewed adopted a combination of three data collection methods (e.g. Islam, 2010; Richardson, et al., 2012; Kim, 2014; Negrușa et al., 2014), while several articles combined two data collection methods (e.g. Alberti, et al., 2011; Ganzaroli and Noni, 2017; Pereira et al., 2020; Ayakwah et al., 2020).

The majority of the empirical research on business clusters used documentary analysis data collection. This method of data collection is used mainly to review qualitative documents to assess an appraisal theme, it requires data be examined and inter- 
preted in order to gain in-depth knowledge of subject matters. This method is often used with other data collection methods as a means of triangulation. There is the need to seek for collaboration through other data source to have credible information. (Zina, 2021). By reviewing data collected from different source, the researcher can corroborate findings which reduces the potential biases that can exist in a single-source study. However, the data collection method is not without its drawback as there may be concealed errors in documentary data (Zina, 2021). Also, data collected may not fully fit in answering research questions (Zina, 20217). These limitations may be the reason why several of the $\mathrm{BC}$ empirical studies reviewed did not rely on documentary analysis as single data collection method but obtained data through other means to corroborate information Therefore, to have a good test of reliability and accuracy, future business cluster research should combine data collection methods.

Table 4 present the key findings of this systematic review of $79 \mathrm{BC}$ articles published in the last 11 years $(2010-2020)$.

Table 4

Summary of findings of review of $79 \mathrm{BC}$ articles

\begin{tabular}{|c|c|c|c|}
\hline $\begin{array}{l}\mathbf{S} / \\
\mathbf{N}\end{array}$ & Heading & Key Findings & Implications \\
\hline 1 & $\begin{array}{l}\text { Time distribution } \\
(2010-2020)\end{array}$ & $\begin{array}{l}>\mathrm{BC} \text { articles were published every } \\
\text { year from } 2010 \text { to } 2020 \\
>2014 \text { witness the highest publication } \\
\text { of } \mathrm{BC} \text { with } 17 \text { articles published. }\end{array}$ & $\begin{array}{l}>\text { Increased interest in the } \mathrm{BC} \\
\text { concept by policy makers to } \\
\text { cope with the economic crisis }\end{array}$ \\
\hline 2 & $\begin{array}{l}\text { Geographic dis- } \\
\text { tribution }\end{array}$ & $\begin{array}{l}>35 \text { Countries had at least one BC } \\
\text { article. } \\
>\text { US had the highest number of BC } \\
\text { articles with } 18 \text { amount contributing } \\
\text { countries. } \\
>\text { Europe had the largest number of } \\
\text { BC articles among the continents, } \\
\text { while Australasia had the least (2). }\end{array}$ & $\begin{array}{l}>\text { There is need for research in } \\
\text { BC in Australasia, South Amer- } \\
\text { ica and Africa as they had the } \\
\text { least of published BC articles. }\end{array}$ \\
\hline 3 & Article type & $\begin{array}{l}>\text { More than } 70 \% \text { of the BC articles } \\
\text { reviewed were based on Empirical } \\
\text { research ( } 56 \text { out of } 79) \text {, while } 23 \text { arti- } \\
\text { cles were conceptual in nature. }\end{array}$ & $\begin{array}{l}>\text { There is need for more con- } \\
\text { ceptual research to be carried } \\
\text { out on business clusters. }\end{array}$ \\
\hline 4 & Theory used & $\begin{array}{l}>35 \text { theories were used in BC articles } \\
\text { reviewed, though significant number } \\
(30 \%) \text { of articles did not use any theo- } \\
\text { ry. } \\
>\text { Business cluster theory }(15.38 \%) \\
\text { had the highest usage in the BC arti- } \\
\text { cles reviewed. }\end{array}$ & $\begin{array}{l}>\text { High number of theories } \\
\text { available for use indicate the } \\
\text { need for more empirical re- } \\
\text { search to test all these theories. }\end{array}$ \\
\hline 5 & BC Theme & $\begin{array}{l}>37 \% \text { investigated the opportunities } \\
\text { and benefit of } \mathrm{BC} \text {, while } 27 \% \text { explore } \\
\text { the evolution and development of } \mathrm{BC} \text {. } \\
>\text { The applicability of } \mathrm{BC} \text { concept in } \\
\text { other areas had the least } \mathrm{BC} \text { articles } \\
(12 \%)\end{array}$ & $\begin{array}{l}>\text { Future research should focus } \\
\text { on the role of government } \\
\text { agency in building a resilient } \\
\text { economy through business } \\
\text { clusters. }\end{array}$ \\
\hline 6 & $\begin{array}{l}\text { Data collection } \\
\text { methods }\end{array}$ & $\begin{array}{l}>\text { Six data collection were the focus of } \\
\text { this review. } \\
>\text { Document analysis was the most } \\
\text { common method adopted (38). }\end{array}$ & $\begin{array}{l}>\text { Future BC research should } \\
\text { adopt combination of data col- } \\
\text { lection methods to provide } \\
\text { more insight into the BC con- } \\
\text { cept. }\end{array}$ \\
\hline
\end{tabular}




\section{CONCLUSION}

There is an increasing awareness of the opportunities and benefits of business clusters in socioeconomic development of local and regional economy. Guidelines must be drawn up by the BC stakeholders with the aim of replicating successful BC strategies in one region to the other developing regions. Research have shown that $\mathrm{BC}$ not only provide enabling environment for MSMEs to grow and perform better but also support businesses during economic crisis (Pereira et a., 2020) through the use of shared facilities. There is increase in the global unemployment rate, thus leading to high poverty especially in Sub-Sahara Africa. Hence, the need for a framework to be drawn up (not a one-size-fit-all system) that will guide each government policy in establishing a vibrant business clusters that will contribute to the economic development (Vernay et al., 2018). Perhaps there is no enough evidence to conclude yet, as Letaifa and Rabeau (2013) suggest, close geographic proximity can impede social development. This is provide the need for more empirical research; as we focus on socioeconomic development, to better understand the impact of BC on MSMEs development.

This study - to this end- conducted a systematic review of business clusters over the last eleven years $(2010-2020)$, this provide the initial goal of establishing the status of the subject matter. $79 \mathrm{BC}$ articles were review across six headings - time distribution, geographical distribution, article type, theory used, article theme, and data collection. Major findings and implications for research for each headings were analysed and discussed.

The highlight of this study shows that significant empirical exists that suggest that there is greater opportunities and benefits in business clusters development. It provides sustainable socioeconomic growth through the entrepreneur development, poverty reduction, employment opportunities and household support, which in turn enhances organizational and regional growth. Major implication for public policy makers to provide the enabling environment where business clusters will thrive, especially the critical resources that will facilitate the entrepreneurial activities in the business cluster.

Despite this study's contribution to the body of knowledge, there exist some limitations that need to be addressed by future BC research. Our findings might have been different if our search criteria is widened. In order to ensure the quality of the articles reviewed, we relied only on journal articles published by seven of the most popular publishers: Emerald, Elsevier, InderScience, Sage, Springer, Taylor and Francis and Wiley. Other valuable articles not published by this published have been excluded. Another limitation is the time bound, only articles published in 2010 to 2020 were reviewed. Future research may include early years as it may provide more useful insight.

However, this study provide a clear picture of the current status of business clusters research and shows a prospect for future research area that need to be addressed in order to achieve the needed benefits of business clusters for regional development by policy makers. 


\section{REFERENCES}

Adebanjo, D., \& Michaelides, R. (2010). Analysis of Web 2.0 enabled e-clusters: A case study. Technovation, 30(4), 238-248. https://doi.org/10.1016/ j.technovation.2009.09.001

Alberti, F. G., Sciascia, S., Tripodi, C., \& Visconti, F. (2011). The entrepreneurial growth of firms located in clusters: a cross-case study. International journal of technology management, 54(1), 53-79. $\quad$ https://doi.org/10.1504/ IJTM.2011.038829

Alberti, F. G., \& Giusti, J. D. (2012). Cultural heritage, tourism and regional competitiveness: The Motor Valley cluster. City, culture and society, 3(4), 261-273. https://doi.org/10.1016/j.ccs.2012.11.003

Alberti, F. G., Giusti, J. D., Papa, F., \& Pizzurno, E. (2014). Competitiveness policies for medical tourism clusters: government initiatives in Thailand. International journal of economic policy in emerging economies, 7(3), 281-309. https:// doi.org/10.1504/IJEPEE.2014.065252

Ali, M., \& Peerlings, J. (2012). Farm households and nonfarm activities in Ethiopia: does clustering influence entry and exit? Agricultural Economics, 43(3), 253266. https://doi.org/10.1111/j.1574-0862.2012.00580.x

Ayakwah, A., Sepulveda, L., \& Lyon, F. (2020). Returning to drive small business exports: diaspora entrepreneurs in Ghana's fruit processing clusters. International Journal of Management and Enterprise Development, 19(3), 273-291.

Letaifa, S. B. \& Rabeau, Y. (2013). Too Close to Collaborate? How Geographic Proximity Could Impede Entrepreneurship and Innovation. Journal of Business Research. 66, 2071-2078

Bourletidis, D. (2014). The strategic model of innovation clusters: Implementation of blue ocean strategy in a typical Greek region. Procedia-Social and Behavioral Sciences, 148, 645-652.

Carlino, G., \& Kerr, W. R. (2015). Agglomeration and Innovation. Handbook of Regional and Urban Economics, 349-404. doi:10.1016/b978-0-444-59517-1.00006 $-4$

Casper, S. (2013). New-technology clusters and public policy: Three perspectives. Social Science Information, 52(4), 628-652.

Champenois, C. (2012). How can a cluster policy enhance entrepreneurship? Evidence from the German 'BioRegio'case. Environment and planning C: government and policy, 30(5), 796-815.

Constantin, D. L., Pauna, C. B., Dragusin, M., Goschin, Z., \& Bodea, C. (2011). The question of clusters in lagging regions: do they really make the difference? A case study in Romania. Environment and Planning C: Government and Policy, 29(5), 889-910.

Dilaver, Ö., Bleda, M., \& Uyarra, E. (2014). Entrepreneurship and the emergence of industrial clusters. Complexity, 19(6), 14-29.

De Sordi, J. O., Meireles, M., \& Nelson, R. E. (2013). Classification of business clusters based on information transfer events. Information development, 29(1), 5468 .

Ferras-Hernandez, X., \& Nylund, P. A. (2019). Clusters as innovation engines: The accelerating strengths of proximity. European Management Review, 16(1), 3753. 
Fowler, C. S., \& Kleit, R. G. (2014). The effects of industrial clusters on the poverty rate. Economic Geography, 90(2), 129-154.

Fundeanu, D. D. (2015). Innovative regional cluster, model of tourism development. Procedia Economics and Finance, 23, 744-749.

Fundeanu, D. D., \& Badele, C. S. (2014). The Impact of Regional Innovative Clusters on Competitiveness. Procedia - Social and Behavioral Sciences, 124, 405-414.

Ganzaroli, A \& Noni I. (2017). The rise of the Chinese regional cluster specializing in fashion in Lombardy: An evolutionary analysis, Journal of Enterprising Communities: People and Places in the Global Economy, 11(4), 491-513.

Garone, L. F., Maffioli, A., de Negri, J. A., Rodriguez, C. M., \& Vázquez-Baré, G. (2015). Cluster development policy, SME's performance, and spillovers: evidence from Brazil. Small Business Economics, 44(4), 925-948.

Glaeser, E. L., Kerr, W. R., \& Ponzetto, G. A. M. (2010). Clusters of entrepreneurship. Journal of Urban Economics, 67(1), 150-168.

Gordon, P., \& Kourtit, K. (2019). Agglomeration and Clusters Near and Far For Regional Development: A Critical Assessment. Regional Science Policy \& Practice, 12(3), 387-396.

Guisard, D., Le Bas, C., \& Nief, P. (2010). The French regional industrial clusters policy: Lessons from the Lyon urban trucks and bus cluster. Local Economy, 25(8), 668-677.

Herliana, S. (2015). Regional innovation cluster for small and medium enterprises (SME): A triple helix concept. Procedia-Social and Behavioral Sciences, 169, 151-160.

Hervas-Oliver, J.-L., Gonzalez, G., Caja, P., \& Sempere-Ripoll, F. (2015). Clusters and Industrial Districts: Where is the Literature Going? Identifying Emerging Sub-Fields of Research. European Planning Studies, 23(9), 1827-1872.

Hervas-Oliver, J. L., Lleo, M., \& Cervello, R. (2017). The dynamics of cluster entrepreneurship: Knowledge legacy from parents or agglomeration effects? The case of the Castellon ceramic tile district. Research Policy, 46(1), 73-92.

Hill, T. L., \& Mudambi, R. (2010). Far from Silicon Valley: How emerging economies are re-shaping our understanding of global entrepreneurship. Journal of International Management, 16(4), 321-327.

Huang, A., Gallegos, L., \& Lerman, K. (2017). Travel analytics: Understanding how destination choice and business clusters are connected based on social media data. Transportation Research Part C: Emerging Technologies, 77, 245-256.

Huggins, R., Morgan, B., \& Williams, N. (2015). Regional entrepreneurship and the evolution of public policy and governance. Journal of Small Business and Enterprise Development, 22(3), 473-511.

Islam, F. (2010). Socioeconomy of innovation and entrepreneurship in a cluster of SMEs in emerging economies. Competitiveness Review: An International Business Journal, 20(3), 267-278.

Kassai, M., Kaspar, J., Deif, A., \& Smith, H. (2018). Exploring farmers markets as a temporary cluster to improve local food economy. British Food Journal, 120(8), 1844-1858.

Kim, S. T. (2014). Regional advantage of cluster development: A case study of the San Diego biotechnology cluster. European Planning Studies, 23(2), 238-261.

Kukalis, S. (2010). Agglomeration economies and firm performance: the case of industry clusters. Journal of Management, 36(2), 453-481. 
Lalzuitluangi, \& Ramswamy, R. (2019). Entrepreneurship Development in Saitual Sericulture Cluster in Mizoram. SEDME (Small Enterprises Development, Management \& Extension Journal), 46(3), 141-151.

Ma, R., \& Liu, W. H. (2019). Spatial Concentration of Innovation Activities in China and the Role of Mega-economic Zones. China \& World Economy, 27(2), 24-43.

Madichie, N. O., \& Nkamnebe, A. D. (2010). 51 Iweka Road (Onitsha, Nigeria): could this single African address redefine business cluster development?. World Review of Entrepreneurship, Management and Sustainable Development, 6(3), 229243.

Mitra, S., \& Thorpe, M. (2010). Government policy, clusters and the'Dubai model'. International Journal of Globalisation and Small Business, 4(1), 73-91.

Negruşa, A. L., Rus, R. V., \& Sofică, A. (2014). Innovative tools used by business networks and clusters in communication. Procedia-Social and Behavioral Sciences, $148,588-595$.

Nishimura, J., \& Okamuro, H. (2011). R\&D productivity and the organization of cluster policy: An empirical evaluation of the Industrial Cluster Project in Japan. The Journal of Technology Transfer, 36(2), 117-144.

Njøs, R., \& Jakobsen, S.-E. (2016). Cluster policy and regional development: scale, scope and renewal. Regional Studies, Regional Science, 3(1), 146-169.

Pereira, V., Temouri, Y., \& Patel, C. (2020). Exploring the role and importance of human capital in resilient high performing organisations: evidence from business clusters. Applied Psychology, 69(3), 769-804.

Pickering, C., \& Byrne, J. (2014). The benefits of publishing systematic quantitative literature reviews for PhD candidates and other early-career researchers. Higher

Education Research and Development, 33(3), 534-548.

Rauch, A., van Doorn, R., \& Hulsink, W. (2014). A qualitative approach to evidencebased entrepreneurship: Theoretical considerations and an example involving business clusters. Entrepreneurship Theory and Practice, 38(2), 333-368.

Richardson, C., Yamin, M., \& Sinkovics, R. R. (2012). Policy-driven clusters, interfirm interactions and firm internationalisation: Some insights from Malaysia's Multimedia Super Corridor. International Business Review, 21(5), 794-805.

Rocha, H. O. (2015). Do clusters matter to firm and regional development growth? Evidence from Latin America. Business Policy and Entrepreneurship, 13(1), 83123.

Rosiello, A., Mastroeni, M., Castle, D., \& Phillips, P. W. (2015). Clusters, technological districts and smart specialisation: an empirical analysis of policy implementation challenges. International Journal of Entrepreneurship and Innovation Management, 19(5-6), 304-326.

Schmiedeberg, C. (2010). Evaluation of cluster policy: a methodological overview. evaluation, 16(4), 389-412.

Selvarajah, C., \& Masli, E. K. (2011). Ethnic entrepreneurial business cluster development: Chinatowns in Melbourne. Journal of Asia Business Studies, 5(1), 42-60.

Steiner, B. E., \& Ali, J. (2011). Government support for the development of regional food clusters: Evidence from Alberta, Canada. International Journal of Innovation and Regional Development, 3(2), 186-216.

Swords, J. (2013). Michael Porter's cluster theory as a local and regional development tool: The rise and fall of cluster policy in the UK. Local Economy, 28(4), 369383. 
Tawfik, G. M., Dila, K. A. S., Mohamed, M. Y. F., Tam, D. N. H., Kien, N. D., Ahmed, A. M., \& Huy, N. T. (2019). A step by step guide for conducting a systematic review and meta-analysis with simulation data. Tropical Medicine and Health, 47(1)

Vernay, A. L., D'Ippolito, B., \& Pinkse, J. (2018). Can the government create a vibrant cluster? Understanding the impact of cluster policy on the development of a cluster. Entrepreneurship \& Regional Development, 30(7-8), 901-919.

Wang, L., Madhok, A., \& Xiao Li, S. (2014). Agglomeration and clustering over the industry life cycle: Toward a dynamic model of geographic concentration. Strategic Management Journal, 35(7), 995-1012.

Wardhana, D., Ihle, R., \& Heijman, W. (2017). Agro-clusters and Rural Poverty: A Spatial Perspective for West Java. Bulletin of Indonesian Economic Studies, 53 (2), 161-186.

Wolman, H., \& Hincapie, D. (2015). Clusters and cluster-based development policy. Economic Development Quarterly, 29(2), 135-149.

Xue, Y., \& Liu, X. (2015). Growth mechanism for cluster entrepreneurship of peasant households. Chinese Management Studies, 9(2), 221-238.

Yan, H. D., Kuo, Y. C., \& Chen, S. Y. (2011). Entrepreneurship and an apprenticebased cluster: the evolution of Houli's saxophone cluster in Taiwan. Global Economic Review, 40(4), 483-502.

Yu, J., Chen, R., Liu, R., Weng, Q., Mao, G., \& Huang, T. (2013). Industrial cluster, government agency and entrepreneurial development. Chinese Management Studies, 7(2), 253-280.

Zina, O. (2021). The essential guide to doing your research project. Sage.

Zubairu, M. U. (2019). Servant Leadership in the Last Decade: A Systematic Review. Journal of Corporate Responsibility and Leadership, 6(1), 53-76. 